\title{
Indoor radon concentration: impact of geology in the 2005 Kashmir earthquake-affected Bagh area, Azad Jammu and Kashmir, Pakistan
}

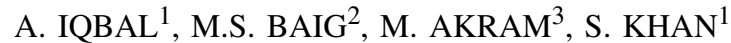

(Manuscript received 17 December 2010, accepted 26 April 2011)

Abstract

The early Miocene Murree Formation, late Miocene Nagri Formation and recent alluvium rock units are exposed in the sub-Himalayas of the Bagh area, State of Azad Jammu and Kashmir, Pakistan. The Bagh area was badly affected by the Kashmir earthquake of October 8th 2005 which, along the Muzaffarabad Fault, deformed both the hanging and footwall blocks. The cracks, joints, fissures and fractures in houses and bedrocks might have affected the emission of radon to the surface. Indoor radon concentration measurements were carried out in some dwellings of the Bagh area, Azad Kashmir, Pakistan. The measurements were based on passive integrative detection of radon using $\mathrm{CN}-85$ plastic track detectors in box-type dosimeters. The radon concentration in dwellings was between $50 \pm 11.6 \mathrm{~Bq} \cdot \mathrm{m}^{-3}$ and $167.1 \pm$ $21.4 \mathrm{~Bq} \cdot \mathrm{m}^{-3}$ with an overall average of $95.1 \pm 15.8 \mathrm{~Bq} \cdot \mathrm{m}^{-3}$ (geometric mean = 93.4 $\mathrm{Bq} \cdot \mathrm{m}^{-3}$ ). The average radon concentrations in pucka, semi-pucka and kucha houses were $97.6 \pm 15.4 \mathrm{~Bq} \cdot \mathrm{m}^{-3}, 89.7 \pm 15.2 \mathrm{~Bq} \cdot \mathrm{m}^{-3}$ and $101.9 \pm 15.9 \mathrm{~Bq} \cdot \mathrm{m}^{-3}$, respectively. The mean values of radon concentrations in the Nagri Formation, Murree Formation and recent alluvium lithology were 99.3 $\pm 15.8,90.1$ and $96.2 \pm$ $15.5 \mathrm{~Bq} \cdot \mathrm{m}^{-3}$, respectively. The annual effective dose to the Bagh population was calculated as $2.38 \pm 0.77(1.33 \pm 0.2$ to $4.7 \pm 0.5) \mathrm{mSv}$. The average radon $(95.1 \pm$ $15.8 \mathrm{~Bq} \cdot \mathrm{m}^{-3}$ ) concentration in dwellings for the inhabitants of the Bagh area was safe from radon-related health hazards and was within the recommended action level (ICRP publication 65 (1993) Protection against radon at home and at work, International Commission on Radiological Protection, Ann. ICRP 23(2)). The indoor radon values obtained in the present study are more than the world average of $40 \mathrm{~Bq} \cdot \mathrm{m}^{-3}$ (UNSCEAR (2000) United Nations Scientific Committee on the Effects of Atomic radiation, Report to the General Assembly, United Nations, New York).

Keywords: Radon / dwellings / annual effective dose / CN 85 / Bagh / Kashmir earthquake 2005

RÉSUMÉ Concentration de radon intérieur : l'impact de la géologie dans la zone Bagh, Azad Jammu et Cachemire, Pakistan affectée par le tremblement de terre de 2005 au Cachemire.

La formation Murree du début du Miocène, la formation Nagri de la fin du Miocène et les unités rocheuses d'alluvions récents sont exposées dans la sous région de l'Himalaya Bagh, Etat d'Azad Jammu et Cachemire, Pakistan. La région de Bagh a été durement touchée par le tremblement de terre du Cachemire du 8 octobre 2005 ,

\footnotetext{
Department of Physics, University of Azad Jammu and Kashmir, Muzaffarabad, Pakistan.

Institute of Geology, University of Azad Jammu and Kashmir, Muzaffarabad, Pakistan.

Physics Research Division, PINSTECH, P.O. Nilore, Islamabad, Pakistan.
} 


\begin{abstract}
qui le long de la faille Muzaffarabad a déformé à la fois les blocs suspendus et ceux de l'éponte inférieure. Les crevasses, les jointures, les fissures et les fractures dans les maisons et leurs soubassements pourraient avoir eu une influence sur les émissions de radon à la surface. Les mesures de concentration en radon à l'intérieur ont été réalisées dans certains logements de la région de Bagh, Azad Cachemire, Pakistan. Les mesures ont été fondées sur la détection passive intégrée de radon à l'aide de dosimètres de type boîte en plastique, à détecteurs de traces $\mathrm{CN}-85$. La concentration en radon dans les habitations variait de $50 \pm 11,6 \mathrm{~Bq} \cdot \mathrm{m}^{-3}$ à $167,1 \pm 21,4 \mathrm{~Bq} \cdot \mathrm{m}^{-3}$ avec une moyenne globale de $95,1 \pm 15,8 \mathrm{~Bq} \cdot \mathrm{m}^{-3}$ (moyenne géométrique $=93.4 \mathrm{~Bq} \cdot \mathrm{m}^{-3}$ ). Les concentrations moyennes de radon dans les maisons de type pucka, semi pucha et kucha étaient respectivement de $97,6 \pm 15,4 \mathrm{~Bq} \cdot \mathrm{m}^{-3}, 89,7 \pm 15,2 \mathrm{~Bq} \cdot \mathrm{m}^{-3}$ et $101,9 \pm$ $15,9 \mathrm{~Bq} \cdot \mathrm{m}^{-3}$.Les valeurs moyennes des concentrations de radon dans la formation Nagri, la formation Murree et les alluvions récents étaient respectivement de 99,3 \pm $15,8 \mathrm{~Bq} \cdot \mathrm{m}^{-3}, 90,1 \mathrm{~Bq} \cdot \mathrm{m}^{-3}$ et $96,2 \pm 15,5 \mathrm{~Bq} \cdot \mathrm{m}^{-3}$. La dose efficace annuelle à la population a été calculée à $2,38 \pm 0,77($ de $1,33 \pm 0.2$ à $4,7 \pm 0,5) \mathrm{mSv}$. La concentration moyenne de radon $\left(95,1 \pm 15,8 \mathrm{~Bq}^{-3}\right)$ dans les logements met les habitants de la région de Bagh à l'abri de risques de santé liés au radon et se situe dans le niveau de l'action recommandée (ICRP publication 65 (1993) Protection against radon at home and at work, International Commission on Radiological Protection, Ann. ICRP 23(2)). Les valeurs de radon à l'intérieur obtenues dans la présente étude sont supérieures à la moyenne mondiale de $40 \mathrm{~Bq} \cdot \mathrm{m}^{-3}$ (UNSCEAR (2000) United Nations Scientific Committee on the Effects of Atomic radiation, Report to the General Assembly, United Nations, New York).
\end{abstract}

\title{
1. Introduction
}

Radon-222 is a ubiquitous radioactive gas which is present in the earth's crust and is released by the decay of radium within the uranium natural decay series. Uranium is present in varying amounts in all rocks and soils; so are radon-222 and radium, because these are the daughter products formed by the radioactive decay of uranium.Radon is transformed into polonium-218 and polonium-214 after following a chain of alpha and beta decays. There is a risk of lung cancer from inhalation of radon due to the alpha radiation emitted by the short-lived radon decay products. The radioactive alpha particles emitted from radon are capable of causing damage to the pulmonary epithelium and thus resulting in lung cancer. The relatively long half-life of radon allows the gas to move from the soil into the houses by diffusion and advection, and it can enter the dwellings from its source in rocks and soil through voids, fractures, cracks in floors, floor drains and construction joints. In indoor environments radon can accumulate to significant levels and the magnitude of its concentration indoors depends primarily on the construction of the building, the amount of radon in the underlying soil, soil characteristics, ventilation rate, atmospheric pressure and even the lifestyle of the people.

Radon is the main source of internal radiation exposure to human life (Durrani, 1993; UNSCEAR, 2000). Therefore, measurement of radon in dwellings is of interest because of the alpha-emitting nature of this radioactive gas in assessing the population exposure to radiation. Several studies have been conducted worldwide 
INDOOR RADON CONCENTRATION

to monitor the radon in dwellings (Barros-Dios et al., 2007; Iimoto et al., 2001; UNSCEAR, 2000). Various authors have attempted to correlate radon concentration with geological parameters (Choubey and Ramola, 1997; Ramola et al., 2005; Sundal et al., 2005). Radon concentrations in the dwellings of Bagh and its surrounding areas were measured using the passive integrating solid state nuclear track detector technique (Fleischer et al., 1975; Akram et al., 2005; Iqbal et al., 2008). The Muzaffarabad Fault passes through the Bagh area, which was badly affected by the large Kashmir earthquake of October 8th 2005, of a magnitude of 7.5 on the Richter scale. This paper attempts to describe the comparison of indoor radon concentration data, with the surficial geology, house construction characteristics and construction material used in Bagh, Azad Kashmir, Pakistan. The data generated in the present study will be useful for further such studies and will serve as baseline data in case of any eventuality.

\section{Study area}

Bagh city is the headquarters of Bagh district in the state of Azad Jammu and Kashmir, sub-Himalayas, northeast Pakistan. Bagh is situated at a distance of 205 $\mathrm{km}$ from Islamabad, the capital city of Pakistan. The area represents mountainous terrain and high relief topography. The altitude varies from $1676 \mathrm{~m}$ to $2000 \mathrm{~m}$. The summer and winter temperatures are $22^{\circ} \mathrm{C}$ to $35^{\circ} \mathrm{C}$ and $-5^{\circ} \mathrm{C}$ to $13{ }^{\circ} \mathrm{C}$, respectively. The mean annual rainfall is about $1500 \mathrm{~mm}$. The climate varies from tropical to temperate. It is pleasant during summer and extremely cold in winter. The Bagh area was badly affected by the Kashmir earthquake of 8th October 2005 (ERRA, 2007).

\section{Geology}

The Bagh area lies in the Himalayan mountain belt of northeast Pakistan. The Himalayan mountain belt is the result of tertiary collision between the Indian and Eurasian plates (Wadia, 1931, Baig and Lawrence 1987). The sedimentary rocks in the area are folded, faulted, fractured and jointed due to Himalayan collision. The active Muzaffarabad Fault or Himalayan frontal thrust (Baig and Lawrence, 1987) passes through Allai Kohistan, Balakot, Muzaffarabad, Bagh, Lasdana, Chrikot and Poonch city, Indian-held Kashmir (Baig, 2006). The Muzaffarabad Fault splays into the Raikot Fault. The Muzaddarabad Fault emplaces the Murree Formation on the Nagri Formation. The Muzaffarabad Fault was reactivated during the Kashmir earthquake of 8th October 2005 (Baig 2006). The zone of active landslides, fractures, joints, active ruptures and fissures along the Muzaffarabad Fault provides the passage for the migration of radon to the surface.

The rock units exposed in the area are the early Miocene Murree Formation, late Miocene Nagri Formation and recent alluvium (Fig. 1; Akhtar et al., 2004; 


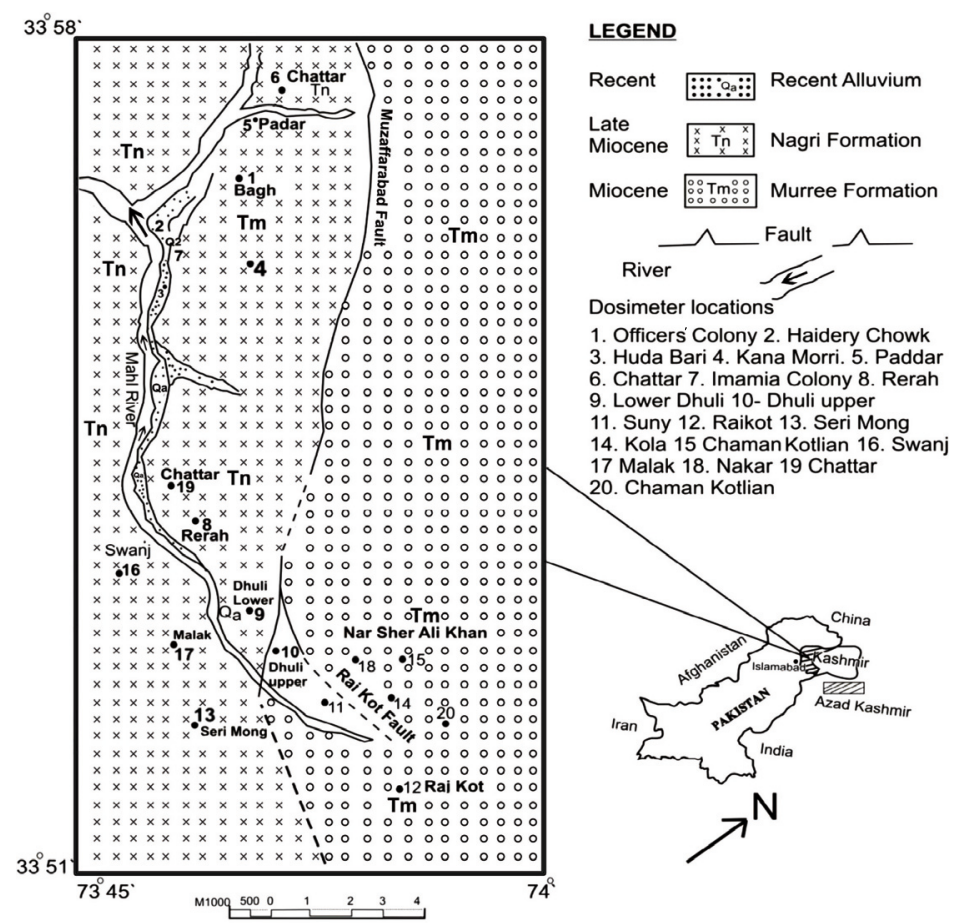

Figure 1 - The geological map showing dosimeter Locations in The Bagh area, Azad Kashmir, Pakistan (modified after Abbasi 2007, Khan 2007).

Carte géologique montrant l'emplacement des dosimètres dans la région de Bagh, Azad Jammu et Cachemir, Pakistan (modifié d'après Abbasi 2007, Khan 2007).

Abbasi, 2007; Khan, 2007). The Murree Formation consists of fine/mediumgrained greenish-gray, gray, red and reddish-brown sandstones and siltstones, and red, purple and purple-maroonish shales and clays. It has minor intraformational conglomerates. The Murree Formation is exposed in the hanging wall block of the Muzaffarabad Fault. The sandstone, siltstone, clay and shale are intruded by quartz and calcite-bearing veins. The Nagri Formation comprises alternating greenishgray, light gray and brownish-gray sandstones, and red to pale red clays. The sandstone dominates the clays. The intraformational and Panjal volcanic clasts are locally present in the Nagri Formation. The sandstone is medium coarse-grained and medium thick-bedded. It shows a salt and pepper texture. The Nagri Formation occurs in the footwall of the Muzaffarabad Fault. The recent deposits are alluvial and fluvial in nature. There are loose sand, silt, clay, gravels and boulders of rivers 
and streams. These recent deposits unconformably overlie the Murree and Nagri Formations. The geological and structural parameters in the area control the variation in radon emission in the area.

\section{Method}

The houses were monitored for radon and data were collected during the summer (July-September, 2009) for 65 days from the houses located on the sedimentary rocks of the Murree Formation, Nagri Formation and recent alluvium. The map in Figure 1 (Akhter et al., 2004; Abbasi, 2007; Khan, 2007) shows the location of the area under study. The radon concentration measurements were based on passive integrative detection of radon (Fleischer et al., 1975). Figure 2 shows the box-type dosimeters made with a plastic frame used in the present study. The dosimeters were suspended inside the rooms at a height of $2.5 \mathrm{~m}$ from the floor. The rooms under investigation were on the ground floor. The dosimeters, after retrieval, were brought to the laboratory and $\mathrm{CN} 85$ detectors were etched chemically with $6.25 \mathrm{~N} \mathrm{NaOH}$ and scanned in the laboratory using an optical microscope at $400 \times$ magnification for the determination of track density. The recorded track density was converted into $\mathrm{Bq} \cdot \mathrm{m}^{-3}$ by using the calibration factor for $\mathrm{CN}-85$ detectors in box-type dosimeters as 0.0092 tracks $\mathrm{cm}^{-2} \mathrm{~h}^{-1}$ equal to $1 \mathrm{~Bq} \cdot \mathrm{m}^{-3}$ of ${ }^{222} \mathrm{Rn}$ (Tufail and Ahmad, 1992; Akram et al., 2005; Tufail et al., 1992; Iqbal et al., 2008). General information about building material and year of construction was also recorded. The construction of houses varied depending upon the type of building material used, ventilation conditions and the dwelling structure. The local pucka, semi-pucka and kucha houses terminology was used during this investigation

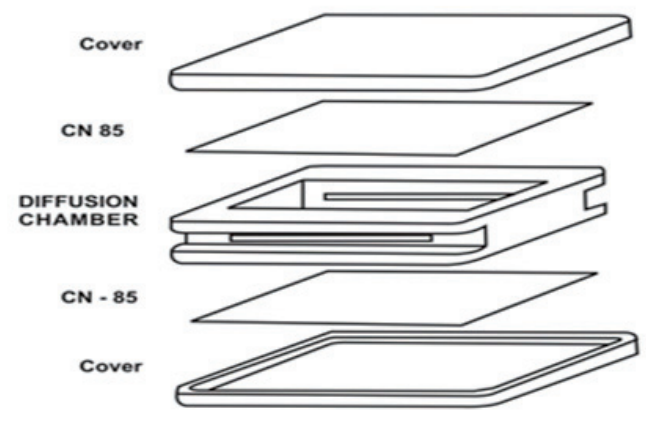

Figure 2 - Box-type dosimeter consisting of two $\mathrm{CN}$-85 detectors employed for radon measurements in dwelling of the Bagh area, Azard Kashmir, Pakistan.

Dosimètre de type bôte constitué de 2 détecteurs $\mathrm{CN}-85$ utilisé pour la mesure du radon dans les habitations de la région de Bagh, Azard Jammu et Cachemire, Pakistan. 
(Iqbal et al., 2008, 2010). The dwellings built of concrete beam and pillar structures, concrete blocks, bricks and sandstone with external and internal cement plaster with roofs and floors of concrete are known as pucka houses. The houses made of sandstone, mudstone and concrete blocks with external and internal cement plaster with mud and timber or steel sheet roofs are known as semi-pucka houses. The houses constructed of mud, mudstone and sandstone with external and internal mud plaster with wooden and mud roofs and earthen floors are referred to as kucha houses. The kucha and semi-pucka houses are poorly ventilated; in contrast, the pucka houses are well ventilated. The houses had only natural ventilation through open windows and doors. The sandstones of the Murree and Nagri Formations have been used in the construction of semi-pucka and kucha houses. The clays of the Murree and Nagri Formations are used in the construction of kucha houses. The sandstone aggregate is from the Murree Formation and Nagri Formation and the sand used in the concrete is from the Mahal River.

\section{Results and discussion}

The radon concentration was measured in houses of the Bagh area, State of Azad Jammu and Kashmir, Pakistan. The radon data and locations are presented in Table I and Figure 1, respectively. The average values of radon concentrations at a particular location are given in the fourth column of Table I. The values within parentheses give the range of radon concentration. The radon concentration in the Bagh area varies from $50 \pm 11.6 \mathrm{~Bq} \cdot \mathrm{m}^{-3}$ to $167.1 \pm 21.4 \mathrm{~Bq} \cdot \mathrm{m}^{-3}$ with an arithmetic mean concentration of $95.1 \pm 15.8 \mathrm{~Bq} \cdot \mathrm{m}^{-3}$ (geometric mean $\left.93.4 \mathrm{~Bq} \cdot \mathrm{m}^{-3}\right)$.

Average indoor radon concentration values of $101.9 \pm 15.9(76 \pm 12.7$ to $167.1 \pm 21.4), 109.7 \pm 16.2(50 \pm 11.6$ to $109.7 \pm 16.2)$ and $97.6 \pm 15.4(73.6 \pm 12.3$ to $131.2 \pm 17.9) \mathrm{Bq} \cdot \mathrm{m}^{-3}$ were obtained in kucha, semi-pucka and pucka dwellings, respectively. The average radon concentration values recorded in kucha houses were higher than the average radon levels in both the pucka and semi-pucka houses. A similar trend has been reported in previous studies (Khan et al., 2008; Reddy et al., 2003).The kucha houses, mostly located in rural areas, are situated close to the active Muzaffarabad Fault and have poor ventilation. These houses feature earthen floors and the high level of radon in these dwellings may be controlled by joints, cracks and fractures in the houses due to earthquake deformation along the active Muzaffarabad Fault. The older pucka houses made of a stone-based interior or exterior recorded relatively higher values of radon concentration than newly constructed pucka houses made of bricks. These old houses show fractures, cracks and joints in walls and basements which provide passage for higher radon migration inside the houses. Figure 3 shows the frequency distribution of radon concentrations in pucka, semi-pucka and kucha dwellings. 
INDOOR RADON CONCENTRATION

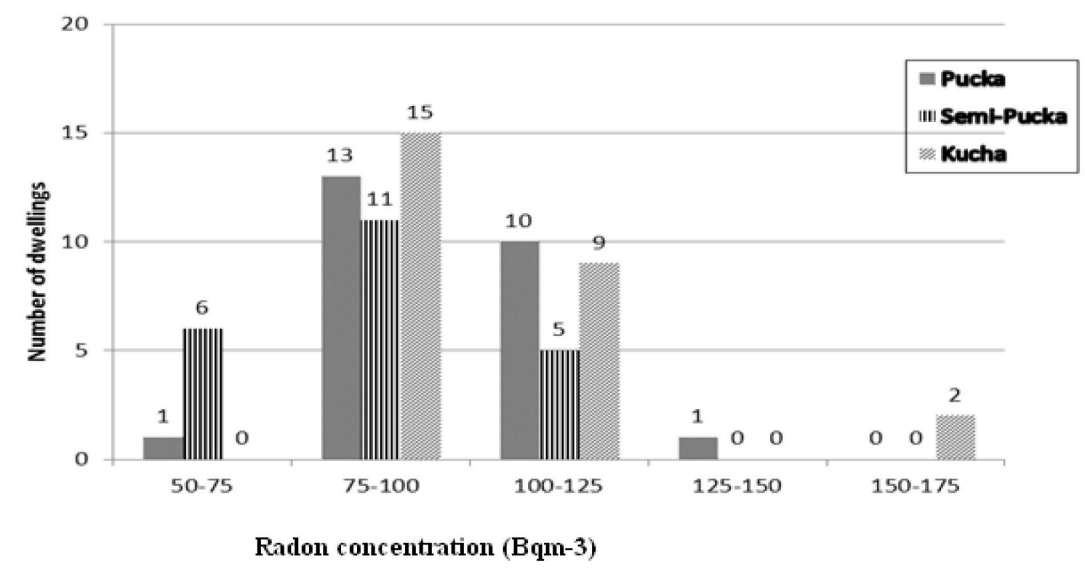

Figure 3 - Frequency distribution of radon concentration in pucka, semi-pucka \& kucha dwellings of the Bagh area, Azard Jammu \& Kashmir, Pakistan.

Distribution de fréquence des concentrations en radon dans les habitations de type pucka, semi-pucka et kucha de la région de Bagh, Azard Jammu Cachemire, Pakistan.

The radon concentrations in the range $0-50,50-75,75-100,100-125$ and $125-150 \mathrm{~Bq} \cdot \mathrm{m}^{-3}$ were $0 \%, 4 \%, 52 \%, 40 \%$ and $4 \%$, respectively, in pucka houses.

The radon concentrations in the range 50-75,75-100 and $100-125 \mathrm{~Bq} \cdot \mathrm{m}^{-3}$, were $27 \%, 50 \%$ and $23 \%$, respectively, in the semi-pucka houses. The radon levels in the range $50-75,75-100,100-125,125-150$ and $150-175 \mathrm{~Bq} \cdot \mathrm{m}^{-3}$ were $0 \%$, $58 \%, 34 \%, 0 \%$ and $8 \%$, respectively, in kucha houses.

The comparison of radon distribution in dwellings situated in various geological subgroups showed that it had an average value of $99.3 \pm 15.8$ $(76.8 \pm 13.2$ to $167.1 \pm 21.4) \mathrm{Bq} \cdot \mathrm{m}^{-3}$ in the Nagri Formation followed by $90.1 \mathrm{~Bq} \cdot \mathrm{m}^{-3}(50 \pm 11.6$ to $114.2 \pm 16.7)$ and $96.2 \pm 15.5 \mathrm{~Bq} \cdot \mathrm{m}^{-3}(70 \pm 12.6$ to $118.9 \pm 17.1$ ) in the Murree Formation and recent alluvium lithology, respectively. The highest average radon concentration was recorded in dwellings of the Nagri Formation exposed to the footwall of the Muzaffarabad Fault in the study area. As regards the lithology of the Nagri Formation, it consists of alternating beds of sandstone, clays and intraformational conglomerates. The sandstone percentage is more than clays, and sandstone of the Nagri Formation is sheared as the active fault passes through this area. This Siwalik group of geological formation presents higher uranium content than the other lithological units (Khan et al., 2005). Volcanic clasts are also observed in this formation. The high average concentration in dwellings located in the Nagri Formation may also be attributed 
TABLE I

The radon concentration data from the dwellings of the Bagh area, Azad Kashmir, Sub-Himalayas, Pakistan.

Concentration en radon dans les habitations de la région de Bagh, Azad Jammu et Cachemire, Sous Himalayas, Pakistan.

\begin{tabular}{|c|c|c|c|c|c|}
\hline S/No. & Location & $\begin{array}{l}\text { Number of } \\
\text { measurements }\end{array}$ & Radon concentration $\mathrm{Bq} \cdot \mathrm{m}^{-3}$ & Dose $\mathrm{mSv} / \mathrm{y}$ & $\begin{array}{l}\text { Geological } \\
\text { formation }\end{array}$ \\
\hline \multicolumn{6}{|c|}{ Pucka houses } \\
\hline 1 & $\begin{array}{l}\text { Officers' } \\
\text { colony }\end{array}$ & 4 & $\begin{array}{c}95.5 \pm 14.7 \\
(77.1 \pm 13.1-115.9 \pm 15.8)\end{array}$ & $2.4 \pm 0.4$ & Nagri Formation \\
\hline 2 & $\begin{array}{l}\text { Haidery } \\
\text { Chowk }\end{array}$ & 2 & $\begin{array}{c}111.15 \pm 15.6 \\
(104.4 \pm 15.2-117.9 \pm 16)\end{array}$ & $2.8 \pm 0.4$ & $\begin{array}{l}\text { Recent } \\
\text { Alluvium }\end{array}$ \\
\hline 3 & Hoda Bari & 4 & $\begin{array}{c}94.9 \pm 15.3 \\
(77.7 \pm 13.1-109.3 \pm 16.3)\end{array}$ & $2.4 \pm 0.3$ & $\begin{array}{l}\text { Recent } \\
\text { Alluvium }\end{array}$ \\
\hline 4 & Kana Moori & 2 & $\begin{array}{c}80.1 \pm 12 \\
(76.8 \pm 13.1-83.3 \pm 12.6)\end{array}$ & $\begin{array}{c}2 \pm 0.3 \\
(1.9 \pm .3-2.1 \pm .3)\end{array}$ & Nagri Formation \\
\hline 5 & $\begin{array}{l}\text { Imamia } \\
\text { Colony }\end{array}$ & 2 & $\begin{array}{c}90.5 \pm 17 \\
(81.9 \pm 15.5-99.1 \pm 18.1)\end{array}$ & $2.3 \pm 0.4$ & $\begin{array}{c}\text { Recent } \\
\text { Alluvium }\end{array}$ \\
\hline 6 & Padar & 2 & $\begin{array}{c}120.3 \pm 16 \\
(109.3 \pm 14.6-131.2 \pm 17.9)\end{array}$ & $\begin{array}{c}3.1 \pm .4 \\
(2.8 \pm .4-3.3 \pm .5)\end{array}$ & Nagri Formation \\
\hline 7 & $\begin{array}{l}\text { Near Bus } \\
\text { Station }\end{array}$ & 2 & $\begin{array}{c}112.5 \pm 15 \\
(109.5 \pm 15.3-115.5 \pm 14.8)\end{array}$ & $2.9 \pm 0.4$ & $\begin{array}{l}\text { Recent } \\
\text { Formation }\end{array}$ \\
\hline 8 & Rehra & 3 & $\begin{array}{c}111.41 \pm 15.9 \\
(93.9 \pm 14.3-118.9 \pm 17.1)\end{array}$ & $2.7 \pm 0.4$ & $\begin{array}{l}\text { Recent } \\
\text { Formation }\end{array}$ \\
\hline 9 & Chatter2 & 2 & $\begin{array}{c}87 \pm 14 \\
(86.7 \pm 15.1-87.3 \pm 13.8)\end{array}$ & $2.1 \pm 0.3$ & $\begin{array}{l}\text { Recent } \\
\text { Alluvium }\end{array}$ \\
\hline 10 & Swanj & 2 & $\begin{array}{c}79.2 \pm 13 \\
(73.6 \pm 12.3-84.9 \pm 14.8)\end{array}$ & $2 \pm 0.3$ & $\begin{array}{l}\text { Recent } \\
\text { Alluvium }\end{array}$ \\
\hline \multicolumn{6}{|c|}{ Average radon concentration pucka houses $=97.6 \pm 15.4 \mathrm{~Bq} \cdot \mathrm{m}^{-3} \mathrm{G} \cdot \mathrm{M}=95.2 \mathrm{~Bq} \cdot \mathrm{m}^{-3}$} \\
\hline \multicolumn{6}{|c|}{ Semi-pucka houses } \\
\hline 11 & Kola & 4 & $\begin{array}{c}78.4 \pm 14 \\
(50 \pm 11.6-100.2 \pm 15.5)\end{array}$ & $\begin{array}{c}1.9 \pm 0.3 \\
(1.3 \pm .2-2.5 \pm .3)\end{array}$ & $\begin{array}{l}\text { Murree } \\
\text { Formation }\end{array}$ \\
\hline 12 & $\begin{array}{l}\text { Chaman } \\
\text { Kotlian }\end{array}$ & 2 & $\begin{array}{c}69.2 \pm 13 \\
(65.7 \pm 13.1-72.6 \pm 13)\end{array}$ & $1.8 \pm 0.3$ & $\begin{array}{l}\text { Murree } \\
\text { Formation }\end{array}$ \\
\hline 13 & Raikot & 1 & $55.2 \pm 11.3$ & $1.3 \pm 0.2$ & $\begin{array}{l}\text { Murree } \\
\text { Formation }\end{array}$ \\
\hline 14 & Sanny & 2 & $\begin{array}{c}99 \pm 14.1 \\
(97.6 \pm 13.8-100.2 \pm 14.3)\end{array}$ & $2.5 \pm 0.2$ & $\begin{array}{l}\text { Murree } \\
\text { Formation }\end{array}$ \\
\hline 15 & Nakar & 1 & $82.8 \pm 13.8$ & $2.1 \pm 0.3$ & Nagri Formation \\
\hline 16 & Lower Dhuli & 3 & $\begin{array}{c}97.6 \pm 14 \\
(88.7 \pm 13.9-109.3 \pm 14.6)\end{array}$ & $2.3 \pm 0.3$ & Nagri Formation \\
\hline 17 & Rehra Bazar & 2 & $\begin{array}{c}84.8 \pm 14 \\
(82.2 \pm 13.5-87.4 \pm 14.2)\end{array}$ & $2.2 \pm 0.3$ & Nagri Formation \\
\hline 18 & Chatter 2 & 2 & $\begin{array}{c}98.8 \pm 16.4 \\
(87.9 \pm 16.6-109.7 \pm 16.2)\end{array}$ & $\begin{array}{c}2.5 \pm 0.4 \\
(2.2 \pm .4-2.8 \pm .4)\end{array}$ & $\begin{array}{l}\text { Nagri } \\
\text { Formation }\end{array}$ \\
\hline
\end{tabular}


TABLE I

Continued

\begin{tabular}{|c|c|c|c|c|c|}
\hline S/No. & Location & $\begin{array}{c}\text { Number of } \\
\text { measurements }\end{array}$ & Radon concentration $\mathrm{Bq} \cdot \mathrm{m}^{-3}$ & Dose $\mathrm{mSv} / \mathrm{y}$ & $\begin{array}{l}\text { Geological } \\
\text { formation }\end{array}$ \\
\hline 19 & Kala Ban & 1 & $78.5 \pm 15.7$ & $2 \pm 0.4$ & $\begin{array}{l}\text { Murree } \\
\text { Formation }\end{array}$ \\
\hline 20 & Swanj & 2 & $\begin{array}{c}100.8 \pm 14.3 \\
(94.9 \pm 14.6-106.7 \pm 14)\end{array}$ & $2.6 \pm 0.4$ & $\begin{array}{l}\text { Nagri } \\
\text { Formation }\end{array}$ \\
\hline 21 & $\begin{array}{c}\text { Mahl } \\
\text { Mohallah } \\
\text { Swanj }\end{array}$ & 2 & $\begin{array}{c}81 \pm 14.1 \\
(70 \pm 12.6-92 \pm 15.6)\end{array}$ & $2.1 \pm 0.3$ & $\begin{array}{l}\text { Recent } \\
\text { Alluvium }\end{array}$ \\
\hline \multicolumn{6}{|c|}{ Average radon concentration semi-pucka houses $=89.7 \pm 15.2 \mathrm{~Bq} \cdot \mathrm{m}^{-3} \mathrm{G} . \mathrm{M} 82.9 \mathrm{~Bq} \cdot \mathrm{m}^{-3}$} \\
\hline \multicolumn{6}{|c|}{ Kucha houses } \\
\hline 22 & Chatter-1 & 2 & $\begin{array}{c}123.4 \pm 17.5 \\
(83.7 \pm 13.4-163.1 \pm 21.6)\end{array}$ & $3.1 \pm 0.4$ & $\begin{array}{l}\text { Nagri } \\
\text { Formation }\end{array}$ \\
\hline 23 & Kola & 4 & $\begin{array}{c}94.4 \pm 15.3 \\
(88 \pm 13.7-105.4 \pm 17.6)\end{array}$ & $2.4 \pm 0.3$ & $\begin{array}{l}\text { Murree } \\
\text { Formation }\end{array}$ \\
\hline 24 & Raikot & 2 & $\begin{array}{c}93.6 \pm 13.9 \\
(90.5 \pm 13.5-96.6 \pm 14.4)\end{array}$ & $2.3 \pm 0.3$ & $\begin{array}{l}\text { Murree } \\
\text { Formation }\end{array}$ \\
\hline 25 & $\begin{array}{l}\text { Chaman } \\
\text { Kotlian }\end{array}$ & 5 & $\begin{array}{c}87.4 \pm 14.4 \\
(76 \pm 12.7-96.6 \pm 14.9)\end{array}$ & $\begin{array}{c}2.2 \pm 0.3 \\
(1.3 \pm 0.3-3 \pm .4)\end{array}$ & $\begin{array}{l}\text { Murree } \\
\text { Formation }\end{array}$ \\
\hline 26 & Raikot & 2 & $\begin{array}{c}99.7 \pm 14.7 \\
(98.9 \pm 15.5-100.4 \pm 13.8)\end{array}$ & $2.4 \pm 0.3$ & $\begin{array}{l}\text { Murree } \\
\text { Formation }\end{array}$ \\
\hline 27 & Sanny & 1 & $106.7 \pm 14$ & $2.7 \pm 0.3$ & $\begin{array}{l}\text { Murree } \\
\text { Formation }\end{array}$ \\
\hline 28 & Nakar & 1 & $106.9 \pm 16.1$ & $2.5 \pm 0.3$ & $\begin{array}{c}\text { Nagri } \\
\text { Formation }\end{array}$ \\
\hline 29 & Dhuli Bazar & 2 & $\begin{array}{c}87.3 \pm 13 \\
(78.9 \pm 12.1-97.6 \pm 14.2)\end{array}$ & $2.2 \pm 0.3$ & $\begin{array}{c}\text { Nagri } \\
\text { Formation }\end{array}$ \\
\hline 30 & Lower Dhuli & 1 & $167.1 \pm 21.4$ & $4.7 \pm 0.5$ & $\begin{array}{c}\text { Nagri } \\
\text { Formation }\end{array}$ \\
\hline 31 & Malak & 2 & $\begin{array}{c}100.7 \pm 14.4 \\
(94.7 \pm 13.4-106.6 \pm 15.4)\end{array}$ & $2.6 \pm 0.3$ & $\begin{array}{c}\text { Recent } \\
\text { Formation }\end{array}$ \\
\hline 32 & Seri Mong & 2 & $\begin{array}{c}82.9 \pm 14.2 \\
(78.2 \pm 13.4-87.6 \pm 15)\end{array}$ & $2.1 \pm 0.3$ & $\begin{array}{l}\text { Nagri } \\
\text { Formation }\end{array}$ \\
\hline 33 & Kala Ban & 2 & $\begin{array}{c}117.6 \pm 17.2 \\
(114.2 \pm 16.7-121 \pm 17.7)\end{array}$ & $2.9 \pm 0.4$ & $\begin{array}{l}\text { Murree } \\
\text { Formation }\end{array}$ \\
\hline
\end{tabular}

Average radon concentration kucha houses $=101.9 \pm 15.9 \mathrm{~Bq} \cdot \mathrm{m}^{-3}\left(\mathrm{G} . \mathrm{M}=97.2 \mathrm{~Bq} \cdot \mathrm{m}^{-3}\right)$

Overall average radon concentration $=95.1 \pm 15.8 \mathrm{~Bq} \cdot \mathrm{m}^{-3}\left(50 \pm 11.6\right.$ to $\left.167.1 \pm 21.4 \mathrm{~Bq} \cdot \mathrm{m}^{-3}\right)$

Overall geometric mean Value $=93.4 \mathrm{~Bq} \cdot \mathrm{m}^{-3}$

to their closeness to the active Muzaffarabad Fault. The active fault, due to high permeability, provides an easy passage for radon to travel more easily upward from depth to the surface. The dwellings constructed on recent alluvium showed a radon concentration value of $96.23 \pm 15.5(70 \pm 12.6$ to $118.9 \pm 17.1) \mathrm{Bq} \cdot \mathrm{m}^{-3}$, which was higher than the average value of $90.1 \mathrm{~Bq} \cdot \mathrm{m}^{-3}$ as observed in the Murree 
Formation. The Murree Formation lies in the hanging wall of the Muzaffarabad Fault and is comprised of cyclic sequences of sandstone and shales with minor conglomerates in places. The recent alluvium is comprised of unconsolidated deposits of silt, clay, cobbles, pebbles and gravel. Sands and gravels are reported to exhalate significantly larger amounts of radon to indoor environments than less permeable soil (Sundal et al., 2005). The high porosity of gravels and pebbles allows more radon to diffuse inside the dwellings through joints, cracks, fractures and fissures, thus increasing the indoor radon levels. The maximum value, $(167.1 \pm 21.4) \mathrm{Bq} \cdot \mathrm{m}^{-3}$, was measured in a kucha house with a mud floor. This maximum value may be due to comparatively poor ventilation and the small cracks observed in the mud floor of this house and also its closeness to the Muzaffarabad Fault. This site was situated in the Nagri Formation and the lithology consists dominantly of blue-gray to khaki-gray sandstones with subordinate khaki-brown clays. The present values of indoor radon concentration in Bagh, Azad Kashmir (Tab. I), were slightly higher than those reported in some dwellings of Rawalpindi, Pakistan(27 to $143 \mathrm{~Bq} \cdot \mathrm{m}^{-3}$, Khan et al., 2005), Islamabad, Pakistan (9 to $36 \mathrm{~Bq} \cdot \mathrm{m}^{-3}$, Tufail et al., 1992), Skardu, Pakistan (76.0 to $152.38 \mathrm{~Bq} \cdot \mathrm{m}^{-3}, \mathrm{Akram}$ et al., 2005), Malwa, India (66.75 to $160.50 \mathrm{~Bq} \cdot \mathrm{m}^{-3}$, Singh et al., 2005a), and Islamabad, Pakistan(11-78 Bq.m ${ }^{-3}$, Rahman et al., 2008).

The radon concentration values obtained in the present investigations in Bagh, Azad Kashmir, were lower than those reported in some dwellings in Hamirpur, India (260.51 to $724.29 \mathrm{~Bq} \cdot \mathrm{m}^{-3}$, Singh et al., 2005b), Parvati valley, India (193 to $356 \mathrm{~Bq} \cdot \mathrm{m}^{-3}$, Choubey et al., 1997), Utter Pradesh, India (19.4 to $2782 \mathrm{~Bq} \cdot \mathrm{m}^{-3}$, Khan et al., 2008b), and Dhirkot, Azad Kashmir (36 \pm 14 to $195 \pm 27 \mathrm{~Bq} \cdot \mathrm{m}^{-3}$, Iqbal et al., 2010). The average value of radon concentration $\left(95.1 \pm 15.8 \mathrm{~Bq} \cdot \mathrm{m}^{-3}\right)$ in the Bagh area is more than the world average of $40 \mathrm{~Bq} \cdot \mathrm{m}^{-3}$ (UNSCEAR, 2000). The overall causes for the higher average radon concentration in dwellings of the Bagh area may be; (1) cracks, fissures and fractures in the basement of older houses, (2) nearness to the active Muzaffarabad Fault, (3) poor ventilation conditions in some houses, (4) the presence of open fractures along the fold axes and faults, (5) bedrock geology, and (6) permeability and soil porosity between fault zones and their side areas. As is evident from Figure 3, nearly $85 \%$ of all the houses showed results lying in the range $75-125 \mathrm{~Bq} \cdot \mathrm{m}^{-3}$. Only $2.7 \%$ of measurements showed radon concentration levels higher than the US EPA action level of $148 \mathrm{~Bq} \cdot \mathrm{m}^{-3}$ (US-EPA, 2009). The data recorded in the present study indicates that the summer indoor radon concentration varies from $(50 \pm 11.6$ to $167.1 \pm 21.4) \mathrm{Bq} \cdot \mathrm{m}^{-3}$ with an overall average value of $95.1 \pm 15.8 \mathrm{~Bq} \cdot \mathrm{m}^{-3}$, which is below the action level of $200 \mathrm{~Bq} \cdot \mathrm{m}^{-3}$ (ICRP, 1993).

The mean radon concentration measured in dwellings was used to estimate the annual effective dose $\mathrm{H}(\mathrm{mSv} / \mathrm{y})$ to inhabitants using the relationship given in 
INDOOR RADON CONCENTRATION

UNSCEAR (2000). The values for the occupancy coefficient, equilibrium equivalent factor and dose conversion factor as mentioned in UNSCEAR (2000), were used to calculate the annual mean effective dose. The average values of the indoor radiation dose due to radon at a particular location for the inhabitants of the Bagh area are given in Table I. The mean values of $2.45 \pm 0.7 \mathrm{mSv} / \mathrm{y}$, $2.15 \pm 0.7 \mathrm{mSv} / \mathrm{y}$ and $2.5 \pm 0.7 \mathrm{mSv} / \mathrm{y}$ were calculated, varying from $(1.9 \pm 0.3$ to $3.3 \pm 0.5),(1.3 \pm 0.2$ to $2.8 \pm 0.4)$ and $(1.3 \pm 0.3$ to $4.7 \pm 0.5) \mathrm{mSv} / \mathrm{y}$ in pucka, semi-pucka and kucha houses, respectively. The mean value for pucka, semipucka and kucha houses considered collectively for all dwellings was calculated as $2.38 \pm 0.77 \mathrm{mSv} / \mathrm{y}$, ranging from $(1.33 \pm 0.2$ to $4.11 \pm 0.5) \mathrm{mSv} / \mathrm{y}$. The average values of the dose in indoor environments were $2.48 \pm 0.8,2.24 \pm 0.5$ and $2.4 \pm 0.7 \mathrm{mSv} / \mathrm{y}$ for the Nagri Formation, Murree Formation and recent alluvium, respectively. The average dose value in the Nagri Formation was higher than in the Murree Formation and recent alluvium. The world mean dose from environmental radon is $1.15 \mathrm{mSv} / \mathrm{y}$ (UNSCEAR, 2000). The average value of the dose, $2.38 \pm 0.77 \mathrm{mSv} / \mathrm{y}$, in the present study was higher than this value. However, the effective dose estimated in the present study is well below the action level of 3-10 mSv/y (ICRP, 1993). In the present study measurements were made during summer (July through September) when indoor radon concentrations are expected to be lower because of high ventilation rates in the dwellings. As it is colder in the winter season in Bagh, there is a possibility that the indoor radon concentration results for exposition around November through February will be higher. Therefore, indoor radon concentration measurements around November through February are recommended in the Bagh area to calculate the annual effective dose, since the influence of the winter radon concentration on the dose could be larger.

\section{Conclusions}

The measured values of radon concentration vary in different categories of dwellings, i.e. pucka, semi-pucka and kucha houses in the Bagh area, Azad Jammu and Kashmir.

The dwellings made of mud with earthen flooring showed higher radon concentration values than in pucka and semi-pucka houses. The measured values were less than the action levels set by various radiation protection agencies. Radon is thus not a big radiological hazard for the dwellers of the Bagh area. The average value of the effective dose calculated in the present study is below the action level (3-10 mSv/y). The radon concentration data collected in the Kashmir earthquakehit Bagh area in this study will serve as a baseline reference for further such studies in the future. These data are also useful in the preparation of a radon map of the area. 
Acknowledgments. The authors are grateful to the University of Azad Jammu and Kashmir, Muzaffarabad, for the provision of research facilities. The help and cooperation received from PINSTECH, Islamabad, is gratefully acknowledged. We wish to thank the residents of dwellings in the study area who agreed to have their houses tested and for their cooperation during the installation and collection of dosimeters in their houses.

\section{REFERENCES}

Abbasi H.R. (2007) Structure, active tectonics, seismotectonics and seismic geohazards microzonation of Chikarkhas and Bagh areas of Eastern Hazara Kashmir Syntaxis, Sub Himalyas, Pakistan, M S Applied Geology Thesis, Institute of Geology, University of Azad Jammu and Kashmir, Pakistan, p. 80

Akhtar S.S., Wali-Ullah, Hussain A., Muhammad R. (2004) Geological map of the Dhirkot area Muzaffarabad and Bagh districts, AJK and parts of Rawalpindi and Abbottabad districts, Geol. Surv., Pakistan, Geol. Map Series, 5-16.

Akram M., Khattak N.U., Iqbal A., Qureshi A.A., Ullah K., Qureshi I.E. (2005) Measurement of radon concentration in dwellings of Skardu city Pakistan, Radiat. Meas. 40, 695-698.

Baig M.S. (2006) Active faulting and earthquake deformation in Hazara-Kashmir syntaxis, Azad Kashmir, northwest Himalayas, Pakistan, Int. Sci. Conf. Earthquake in Pakistan, its implications and hazard mitigations, Islamabad, pp. 20-21.

Baig M.S., Lawrence R.D. (1987) Precambrian to early Paleozoic orogenesis in the Himalayas, Kashmir J. Geol. 5, 1-22.

Barros-Dios J.M., Ruano-Ravina A., Gastelu-Iturri J., Figueiras A. (2007) Factors under laying residential radon concentration: results from Galicia, Spain, Environ. Res. 103, 185-190.

Choubey V.M., Ramola R.C. (1997) Corelation between geology and radon levels in groundwater, soil and indoor air in Bhilangana valley, Garhwal Himalayas, India, Environ. Geol. 32, 258-262.

Choubey V., Sharma K.K., Ramola R.C. (1997) Geology of radon occurrence around Jari in Parvati valley, Himachal Pradesh, India, J. Environ. Rad. 34, 139-147.

Durrani S.A. (1993) Radon as a health hazard at home: what are the facts? Nucl. Tracks Radia Meas. 22, 303-317.

ERRA (2007) Earthquake reconstruction and Rehabilitation Authority Islamabad, District Profile Bagh.

Fleischer R.L., Price P.B., Walker R.M. (1975) Nuclear tracks in solids: principles and Applications. University of California Press, Berkley, pp. 1-200.

ICRP publication 65 (1993) Protection against radon at home and at work, International Commission on Radiological Protection, Ann. ICRP 23(2).

Iimoto T., Kosako T., Sugiura N. (2001) Measurement of summer Radon and its progeny concentrations along with environmental gamma dose rates in Taiwan, J. Environ. Rad. 57, 57-66.

Iqbal A., Baig M.S., Akram M., Abbasi S.A. (2010) Indoor radon concentration, outdoor Gamma dose rates and impact of geology in the Dhirkot areas, Azad Jammu and Kashmir, sub-Himalayas, Pakistan, Radioprotection 45, 523-535.

Iqbal A., Baig M.S., Akram M., Kazmi A., Saleem S., Qureshi A.A. (2008) Indoor Built Environ. 17, 397-402.

Khan M.R. (2007) Structure, active tectonics, seismotectonics and seismic geohazards microzonation of Bagh and Lasdana areas, Sub Himalyas, Pakistan. Thesis M S Applied Geology, Institute of Geology, University of Azad Jammu and Kashmir, Pakistan, p. 79. 
INDOOR RADON CONCENTRATION

Khan M.S., Naqvi A.H., Azam A. (2008) Study of indoor radon and its progeny levels in rural areas of north India using LR-115 plastic track detectors, Radiat. Meas. 43, S385-S388.

Khan S.A., Ali S., Tufail M., Qureshi A.A. (2005) Radon concentration levels in Fatima Jinnah Women University Pakistan, Radioprotection 40, 11-27.

Rahman S.U., Anwar J., Matiullah (2008) Measurement of indoor radon concentration levels in Islamabad, Pakistan, Radiat. Meas. 43, S401- S404.

Ramola R.C., Negi M.S., Choubey V.M. (2005) Radon and thoron monitoring in theEnvironment of Kumaun Himalayas: survey and outcomes, J. Environ. Radioact. 79, 85-92.

Reddy M.S., Reddy B.S., Reddy C.G., Reddy P., Reddy K.R. (2003) Study of indoor radon and its progeny concentrations levels in the surrounding areas of Hyderabad, Andhra Pradesh, India, Radiat. Meas. 36, 507-510.

Singh S., Kumar A., Singh B. (2005b) Passive integrating radon studies for environmental monitoring in Hamirpur district, Himachal Pradesh, India using solid state nuclear track dectectors, Radiat. Meas. 39, 81-85.

Singh S., Mehra R., Singh K. (2005a) Seasonal variation of indoor radon in dwellings of Malwa region, Punjab, Atmos. Environ. 39, 7761-7767.

Sundal A.V., Henriksen H., Soldal O., Strand T. (2005) The influence of geological factors on indoor radon concentrations in Norway, Sci. Total Environ. 328, 41-53S.

Tufail M., Ahmad N. (1992) Measurement of radon in some cities of Pakistan and assessment of excess lung cancer risk, Nucl. Sci. J. 29(4), 263-272.

Tufail M., Khan M.A., Ahmed N., Khan H.A., Zafar M.S. (1992) Measurements of radon concentration in some cities of Pakistan, Radiat. Prot. Dosim. 40 (1), 39-44.

UNSCEAR (2000) United Nations Scientific Committee on the Effects of Atomic radiation, Report to the General Assembly, United Nations, New York.

US Environmental Protection Agency (2009) A citizen guide to Radon EPA 402/K-09/001.

Wadia D.N. (1931) The syntaxis of the Northwest Himalaya: its rocks, tectonics and orogeny, Mem. Geol. Surv., Indian Records 65, 185-370. 